\title{
GENDER DIFFERENCES IN PREFERENCES OF INDIVIDUAL AND TEAM SPORTS IN POLISH ADOLESCENTS
}

\author{
Filip Křen, Michal Kudláček, Wojciech Wąsowicz*, Dorota Groffik*, Karel Frömel
}

\author{
Faculty of Physical Culture, Palacký University, Olomouc, Czech Republic \\ * Academy of Physical Education, Katowice, Poland
}

Submitted in December, 2011

BACKGROUND: The prevalence of physical activity (PA) depends greatly on the options of executing preferable and favorite PA. Objective information about individual preferences in types of PA can support successful integration of adolescents into regular participation in PA. Defining the role of individual and team sports in regard to girls' and boys' sport preferences is a permanent problem that requires objective and continuous diagnostics.

OBJECTIVE: The purpose of the study is to examine the relationship among girls' and boys' preferences in individual and team sports and further among these preferences and PA participation.

METHODS: Online research was conducted in the Katowice region and 518 boys and 559 girls from the age of 15 to 17 years participated. All high schools in the region were called on for participation, but only schools that allowed the research examination participated. Sport preferences survey that participants completed online via INDARES system was used to diagnose preferences in individual and team sports. The results were analyzed using basic statistical procedures, the relationship was determined based on rank correlation coefficients and differences between orders of preferred sports were tested by Mann-Whitney test.

RESULTS: The most preferred individual sport in girls and boys is swimming, and that applies for all age groups. There is a very strong correlation ( $\mathrm{rs}=.841-.895 ; \mathrm{p}<.001$ ) among girls' and boys' ( 15 to 17 years old) preferences in individual sports. Volleyball is the most preferred team sport for girls followed by basketball and handball. The most preferred team sport for boys is soccer by distantly followed by volleyball and basketball. The relationship between girls' and boys' team sports is not as strong as for individual sports $(\mathrm{rs}=.745-.763 ; \mathrm{p}<.001)$. In regard to selected sports, boys and girls corresponded in their team sports preferences followed by individual sports preferences. The highest difference in preferences was evident in the group of rhythmic and dancing activities, which were ranked third by girls, while boys ranked them last. Both girls and boys who prefer individual sports and girls who prefer team sports participate longer in hourly range of organized PA.

CONCLUSIONS: The Polish version of the online system INDARES is a suitable diagnostic tool for the examination of sport preferences sphere in adolescents. Understanding gender differences in sport preferences of adolescents can increase their participation in organized PA.

Keywords: Online research, type of physical activity, preference, swimming, volleyball, INDARES.

\section{INTRODUCTION}

Character and preferences of various types of physical activity (PA) of adolescents vary greatly in different educational systems and socio-cultural conditions. In different socio-cultural conditions are the highest differences still found between girls and boys (Aaron, Storti, Robertson, Kriska, \& Laporte, 2002). That is related to the sound differences in socialization and upbringing of both genders (McHale, Crouter, \& Whiteman, 2003). Children embrace behavioral traits that are perceived by society as "typical" for particular gender and when they enter the first grade in the elementary school they already express behavioral patterns appropriate for the masculine or feminine stereotype. It is also the result of more or less successful socialization in the particular culture (Alexander, 2003; Pryor, 1994).

Since girls are less physically active than boys (Azevedo, Araujo, Da Silva, \& Hallal, 2007; Kjønniksen, Torsheim, \& Wold, 2008; Sigmundová, El Ansari, Sigmund, \& Frömel, 2011), it is more than important to understand the specifics of PA in girls (but also boys) and their preferences. Understanding these specifics can increase the effectiveness of potential interventions in physical programs (school, public) that were created in attempt to support PA in children and adolescents (Pate et al., 2010).

Current Polish educational system (similarly to systems of other post communist countries), in spite of attempts for change, is suited better for feminine types of behavior where teachers demand especially discipline, 
subordination, behavioral control, focus, willingness to submit to leadership, etc. Consequently, many teachers still prefer rigid, conforming, respectful, thoughtful, passive, calm, and neat students rather than students who are nonconformist, flexible, active, independent, and so on. Preferable characteristics have predominantly feminine traits.

Decreasing differences between feminine and masculine sports is to a certain degree a result of the social philosophy of activists/reformers who try to declassify traditional sports to the masses of women and also a result of feminists' critique of positivistic traditions in sport psychology (Cratty, 1983; Singer, Murphey, \& Tennant, 1993). Formerly women were neglected in sports and the majority of studies were conducted only with the male population. Currently it seems appropriate to conduct comparative studies or only studies with the female population. There was also a trend to look at masculine and feminine sports as two distinct units that were absolutely unrelated. However, the reason for that was spurious (physiological rightfulness, series of similarities, etc.). Therefore, it suggests itself that these two units should be unified and only certain specifics that are particular for males or females should be set aside (Singer, Murphey, \& Tennant, 1993; Wilson \& Spink, 2009).

Everyday activities of children and adolescents represent important developmental opportunities that serve as a tool for socialization and cultural knowledge and skill acquisition. The youth population selects various activities to actively engage in, activities that can and often do create their lifestyle and habits associated with it (Kjønniksen, Torsheim, \& Wold, 2008). Identification of the activities preferred by boys and girls is important especially because various activities can enhance different cognitive, social, and motor skills and moreover, because these gender-related interests/preferences change with age. Boys incline more to intense activities, activities that are more physically demanding and team sports while girls incline to participate in sedentary activities, individual sports, and uncompetitive sport activities (Bradley, McMurray, Harrell, \& Deng, 2000; Faucette et al., 1995). Cherney and London (2006) in their study emphasized the fact that gender related preferences are present across all domains of human life (including PA) and those differences are more evident in younger individuals.

In the interest of strengthening the role of physical education (PE) at schools PE teachers should respect students' preferences and needs when choosing activities for particular educational units (Greenwood \& Stillwell, 2001; Pate, Dowda, O’Neill, \& Ward, 2007). PE can more likely survive and increase its prestige if the activities preferred by both boys and girls are included in the educational PE units. There are many factors that can influence students' selection or preferences of sport activities. These include sport and environmental influ- ence, gender, age, skill level and individual's level of PA outside the school (Eyler, Nanney, Brownson, Lochman, \& Haire-Joshu, 2006; Frömel, Formánková, \& Sallis, 2002; Hill \& Cleven, 2005).

Bradley, McMurry, Harrell, and Deng (2000) indicate that girls at high schools prefer uncompetitive or individual sport activities, while boys at the same age incline to team sports. Hill and Cleven (2005) further indicate that adolescent girls participate more often in individual or noncontact sport activities such as swimming, volleyball, aerobics, gymnastics, and jumping rope, while boys more often choose contact or power sports such as working out, hockey, or soccer. Research done with high school students shows that boys prefer to participate in physical activities that give them the opportunity to experience competition, while girls focus more on social parameters of physical activities (Greenwood \& Stillwell, 2001).

The purpose of the present study is to examine the relationships among boys' and girls' preferences in individual and team sports and further among these preferences and boys' and girls' participation in an organized PA. Particularly: 1) Describe and compare the sport preferences in individual and team sports of boys and girls in different age groups; 2) Describe the girls' and boys' participation in organized physical activity from the aspect of individual and team sports preferences.

\section{METHODS}

\section{Data description}

Online research was conducted in the Katowice region and 1,131 students participated in the study (TABLE 1). All high schools in the region were invited to participate but only individuals from the schools that agreed with the research participated. All participants gave researchers their consent to participate in the study and to complete a sport preferences questionnaire.

\section{TABLE 1}

Sample characteristics

\begin{tabular}{|c|c|c|c|c|}
\hline \multirow{2}{*}{ Characteristics } & \multicolumn{2}{|c|}{$\begin{array}{c}\text { Boys } \\
(\mathrm{n}=518)\end{array}$} & \multicolumn{2}{|c|}{$\begin{array}{c}\text { Girls } \\
(\mathrm{n}=559)\end{array}$} \\
\hline & $M$ & $S D$ & $M$ & $S D$ \\
\hline Age (Years) & 16.51 & 1.35 & 16.52 & 1.06 \\
\hline Weight (kg) & 67.47 & 12.11 & 56.70 & 8.68 \\
\hline Height (cm) & 177.19 & 8.34 & 166.24 & 5.93 \\
\hline BMI $\left(\mathrm{kg} \times \mathrm{m}^{-2}\right)$ & 21.50 & 3.21 & 20.49 & 2.73 \\
\hline Organized PA (hours) & 5.17 & 5.23 & $3.21 * * *$ & 3.34 \\
\hline $\begin{array}{l}\text { Organized PA } \\
\text { (participation \%) }\end{array}$ & 81.10 & - & 76.90 & - \\
\hline
\end{tabular}

Legend: PA - physical activity, $* * *$ - statistical significance $\mathrm{p}<.001$ 


\section{Sport preferences questionnaire}

A sport preferences questionnaire that participants completed via the online system INDARES (http://www. indares.com) was used to determine the preferences in individual and team sports (Křen, Chmelík, Frömel, Fical, \& Kudláček, 2008). The questionnaire included seven groups of sport activities - individual sports, team sports, conditional activities, water sport activities, outdoor sport activities, martial arts, rhythmic and dancing activities. Only results from the groups of individual and team sports were used in the study. Furthermore, overall preferences related to particular groups of sports activities were used.

In regard to standardization of the questionnaire, stability was tested using the test-retest and Spearman correlation coefficient (rs). The highest stability between the first and the second measurements were in the group of team sports $(0.81,0.76$ respectively). The biggest stability was then recorded for the group of rhythmic and dancing activities and martial arts $(0.62$, 0.68 respectively for rhythmic and dancing activities; $0.68,0.61$ respectively for martial arts) (Sigmund, Mitáš, Kudláček, \& Frömel, 2007).

\section{Procedures}

Data were collected in computer labs in selected schools. Participants completed the questionnaire in the online system while supervised always by the same members of the research team in order to secure the identical introductory information for research completion. Participants' questioned only the differentiation of organized and unorganized PA in relation to teachers', coaches', instructors' etc. leadership.

The completion of the sport preferences questionnaire includes several steps. First, it is examined, whether participants engage in organized PA or not. Then, researchers investigate in which activities students participate the most during summer and winter. The subsequent forms already contain particular groups of PA and participants are asked to select up to 5 activities from the offered lists. They are asked to arrange the activities in descending order starting with their most favorite activity. There is no required number of activities they have to enter so in extreme cases it can happen that there will be no activities recorded for a particular group. The system will notify the user, but will not require a response. This way participants record individual sports, team sports, conditional activities, water sport activities, outdoor sport activities, martial arts, rhythmic and dancing activities. The last form is dedicated to the groups in general and to the selection of the overall most favorite activity.

Data analysis is conducted in several steps. First, researchers' set point values for particular PA. If PA was entered by a participant, its point value equals to the position of that PA in the participant's ranking. If the participant did not record any activity within a par- ticular group, its value has to be counted according to the following formula - (PAS + PZAS +1$) / 2$ where PAS stands for the overall number of activities in a particular group and PZAS stands for the number of activities that were recorded by a participant in the group. The next step is matching the point value with the sports group using the same principle as for the individual activities. Therefore, the most favorite PA, respectively sports groups, has the lowest values in the overall summary.

An evaluation of the most favorite activity follows. That makes sense especially for a larger group of participants. Votes for particular activities are added up and at the end researchers create a ranking of activities that were mentioned most frequently.

The last step is an evaluation of PA characteristics. A list of 39 characteristics that may specify participants' personal traits according to the selected PA was created. A team of specialists further processed a table where point values of all characteristics were specified for each activity. The range of the values is 1 to 5 , decimal numbers can be used. Value 1 means a high integration of the particular characteristic in PA while value 5 means the lowest integration of the particular characteristic.

Only activities that were placed on the first position in the ranking for a particular group were added to the computation of the overall values in certain characteristics. In case there was no PA in some groups, averages of the characteristics from the recorded groups were computed and added to the overall point values. To refine the computation and to enable a comparison of individual characteristics among each other, researchers also included an overall characteristic point power. Point value for the characteristics is thus adjusted with the following formula $-(\mathrm{SZB} / \mathrm{CBC}) \times 100$.

SZB is an overall value of obtained points for given characteristic and $\mathrm{CBC}$ is an overall computation of point characteristics for all PA. Therefore, the final table enables us to observe which characteristics within physical activities are preferred by an individual, eventually the whole group. Characteristics with the lowest number of points are the most preferred ones, while those with the highest values are represented in a selected PA less. Eight boys and 7 girls had to be excluded from the study during data analysis because they did not correctly indicate their somato-metric parameters or age.

\section{Data analysis}

For statistical analysis in StatisticaCZ 9 and SPSS 19.0 we used basic statistical procedures, Mann-Whitney U test, correlation analysis (rs) and d "effect size" coefficient (Cohen, 1988; Cortina \& Nouri, 2000). We interpret coefficient $d$ as a small effect size when $0<\mathrm{d}<0.2$; medium effect size when $0.2 \leq \mathrm{d}<0.8$; and a large effect size when $d \geq 0.8$ (Cohen, 1988). One hour of a documented PA is considered to be empirically important in a weekly organized PA (Pate et al., 2010). 


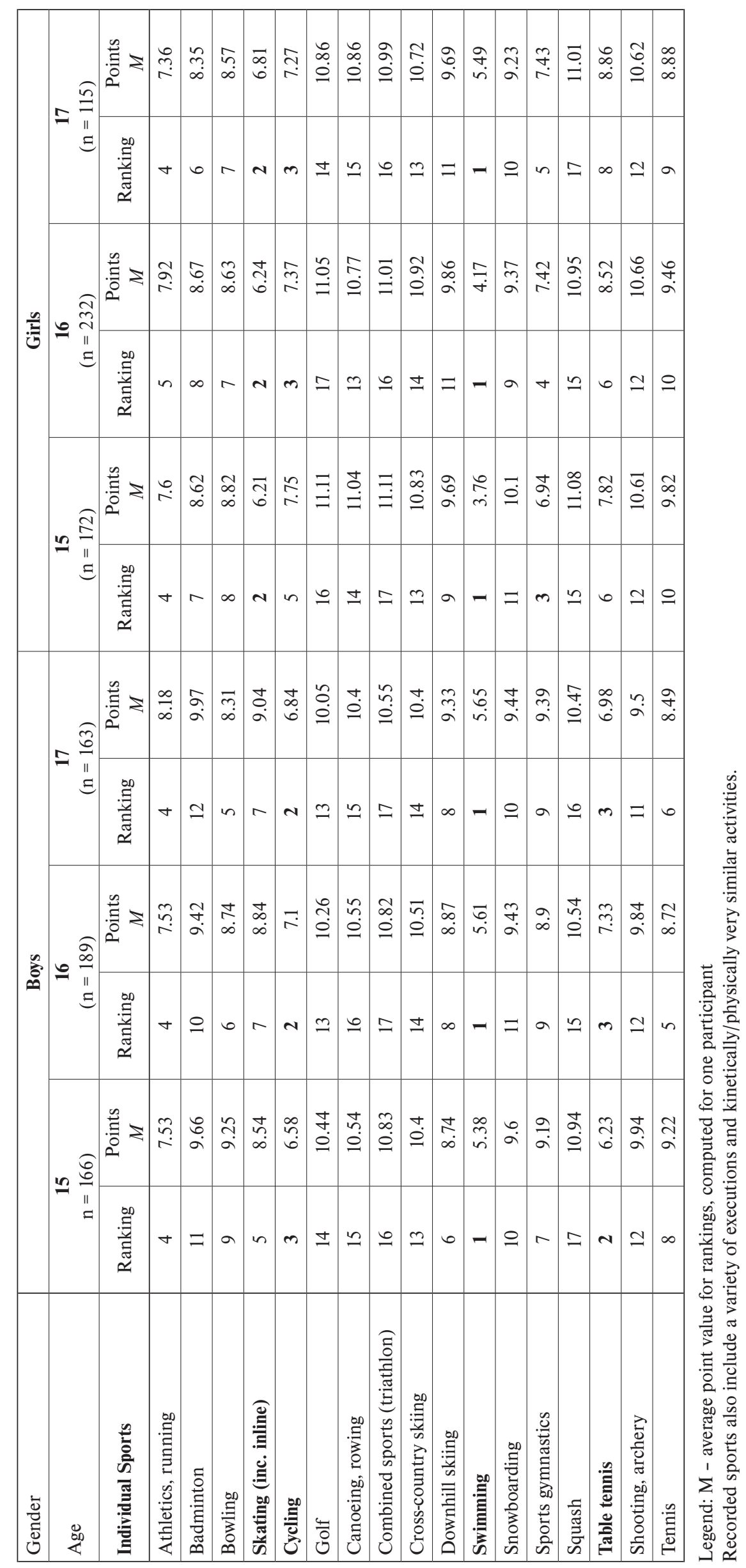




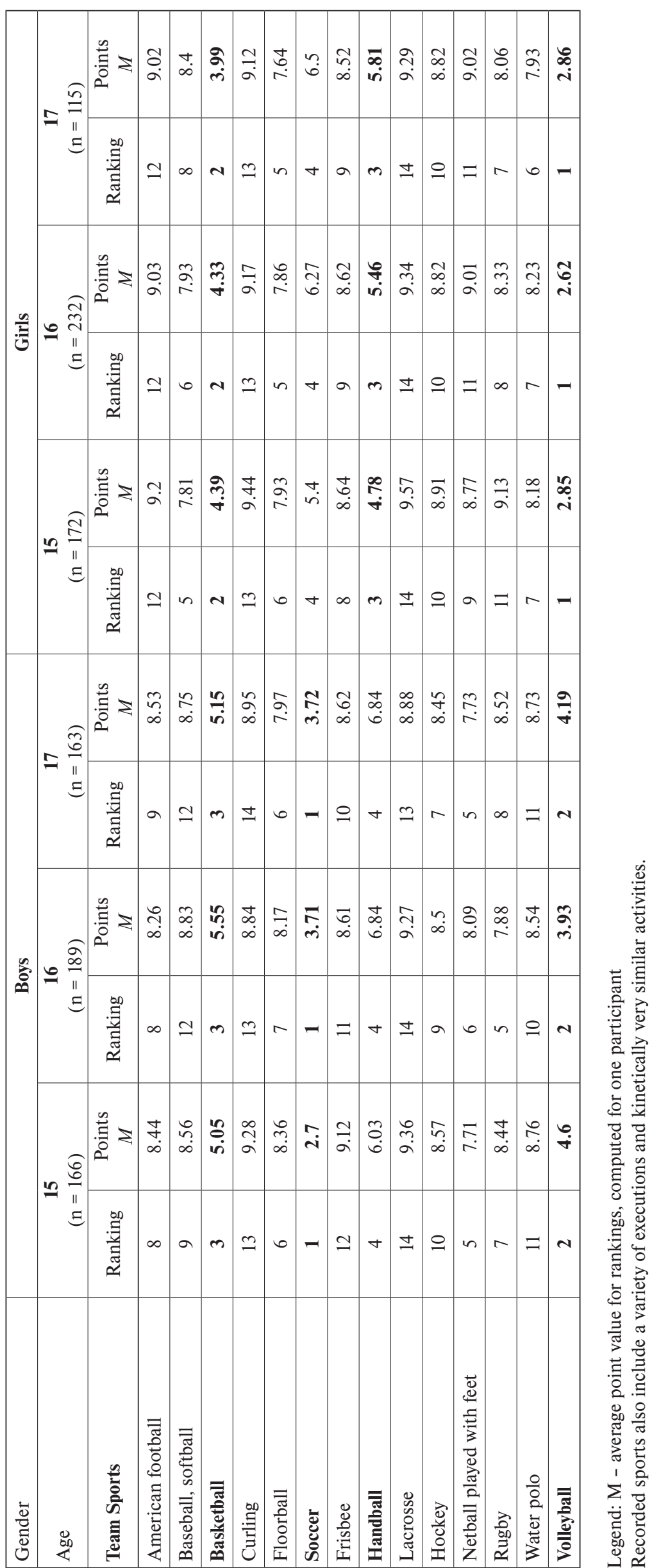




\section{RESULTS}

The most preferred individual sport in girls is swimming and that applies to all age groups (TABLE 2). The second position for girls belongs to skating (inc. inline) and the third to sport gymnastics in 15 year old girls and to cycling for both older groups of girls (16 and 17 year old girls). As well as girls, boys of all age groups prefer swimming in individual sports. The second place for the youngest boys belongs to table tennis and the third to cycling, while older boys prefer cycling in front of table tennis. There is a strong positive correlation among the preferences of individual sports regarding gender for 15 year old boys and girls ( $\mathrm{rs}=.895 ; \mathrm{p}<.001)$, 16 years old $(\mathrm{rs}=.841 ; \mathrm{p}<.001)$ and also 17 years old $(\mathrm{rs}=.841$; $\mathrm{p}<.001)$.

In regard to team sports, volleyball dominated for girls followed by basketball and handball which however also included another type of ball game similar to dodgeball (TABLE 3). Soccer dominated by far for boys ahead of volleyball and basketball. The hypothesis that Polish adolescents still prefer typical traditional European sports was confirmed.

There was not such a strong relationship among the preferences of team sports in boys and girls as it was among the preferences of individual sports. In spite of that, the correlation coefficient that was found was very high for 15 year old boys and girls ( $r s=.763$; $p<.001$ ), and 16 years old $(\mathrm{rs}=.745 ; \mathrm{p}<.001)$, and also 17 years old $(\mathrm{rs}=.754 ; \mathrm{p}<.001)$.

Among the selected groups of sports boys and girls agreed in preferences of team sports followed by individual sports (Fig. 1). They also corresponded in the placement of outdoor sport activities. The biggest difference in the placement of preferences is recorded in the group of rhythmic and dancing activities, which girls placed on the third place, while boys ranked them last.

A significant difference between organized PA participation (expressed in hours of participation) and preferences of individual sports was found in boys $(\mathrm{U}=2.32$; $\mathrm{p}=.021 ; \mathrm{d}=.20)$ and girls $(\mathrm{U}=2.20 ; \mathrm{p}=.028 ; \mathrm{d}=.19)$. In regard to team sports, there was a significant difference only in girls $(U=3.18 ; p=.002 ; d=.26)$. It indicates that preferences of individual sports in boys and girls and team sports in girls are associated with participation in organized PA (expressed in hours of participation).

The most frequently practiced unorganized PA during the summer season was soccer for boys and swimming for girls (TABLE 4). Organized PA is such a physical activity with an organized group that has a coach, instructor, or leader. Further, during winter both boys and girls indicate skiing activities as their most frequent ones (downhill, cross-country, and snowboarding).
Fig. 1

Boys' $(n=518)$ and girls' $(n=559)$ preferences in groups of sports

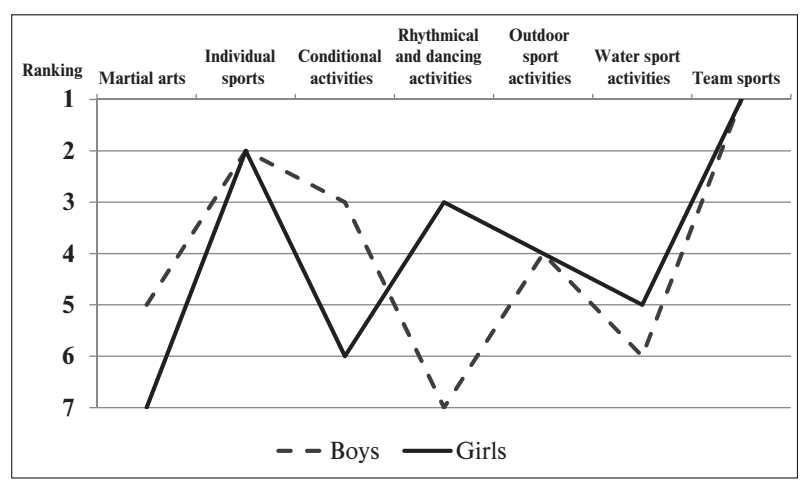

Fig. 2

Boys' $(n=518)$ and girls' $(n=559)$ participation in organized physical activity from the aspect of individual and team sports preferences

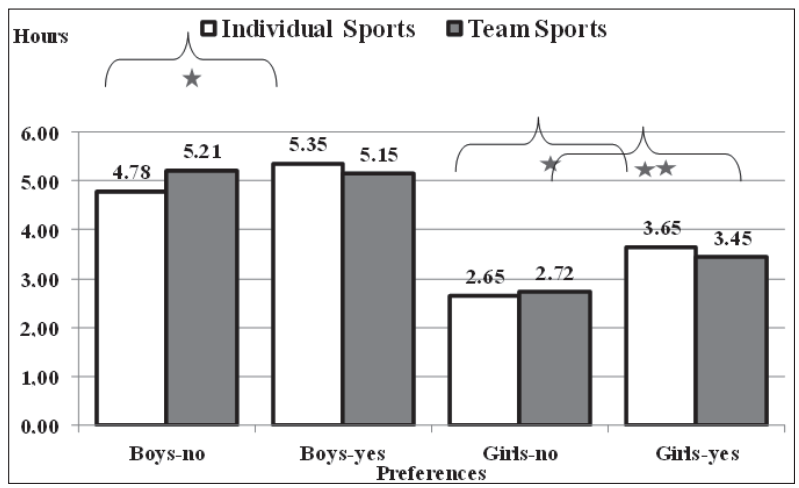

Legend: ${ }^{*} \mathrm{p}<.05,{ }^{* *} \mathrm{p}<.01$

\section{DISCUSSION}

Taking various age groups into consideration, we are able to anticipate potential development, possibly the stability of preferred sport activities within the preference structure. This research conducted with the population of Polish adolescents indicates gender differences and the biggest variation in preferences for the group of individual and team sport activities.

The preference of swimming over other individual sports is obvious even without respect to participants' age and gender. Very good ranking of cycling and athletics (including running activities) corresponds to the current trends (Frömel, Novosad, \& Svozil, 1999; Kudláček, 2010). Sport gymnastics (understood by adolescents in broader terms as gymnastic activities) ranked third by 15 year old girls indicates the importance of including gymnastic exercises to schools and out of school 
TABLE 4

Composition of the most frequent physical activities during winter and summer declared by boys and girls (number of participants in \%)

\begin{tabular}{|c|c|c|c|c|}
\hline \multirow{3}{*}{$\begin{array}{c}\text { Ranking } \\
\text { Type of PA } \\
\text { (\%) }\end{array}$} & \multicolumn{4}{|c|}{ Season of the year } \\
\hline & \multicolumn{2}{|c|}{ Summer } & \multicolumn{2}{|c|}{ Winter } \\
\hline & Boys & Girls & Boys & Girls \\
\hline 1 & $\begin{array}{l}\text { Soccer } \\
(23.4)\end{array}$ & $\begin{array}{c}\text { Swimming activities } \\
(18.8)\end{array}$ & $\begin{array}{l}\text { Skiing activities } \\
\text { (11.8) }\end{array}$ & $\begin{array}{c}\text { Skiing activities } \\
(13.2)\end{array}$ \\
\hline 2 & $\begin{array}{l}\text { Athletics, running, jogging } \\
\text { (14.5) }\end{array}$ & $\begin{array}{l}\text { Athletics, running, jogging } \\
\text { (13.4) }\end{array}$ & $\begin{array}{l}\text { Soccer } \\
(10.0)\end{array}$ & $\begin{array}{c}\text { Skating } \\
12.3)\end{array}$ \\
\hline 3 & $\begin{array}{c}\text { Cycling activities } \\
(8.9)\end{array}$ & $\begin{array}{l}\text { Volleyball } \\
(12.7)\end{array}$ & $\begin{array}{l}\text { Athletics, running, jogging } \\
(9.5)\end{array}$ & $\begin{array}{c}\text { Swimming activities } \\
(12.0)\end{array}$ \\
\hline 4 & $\begin{array}{c}\text { Swimming activities } \\
(8.5)\end{array}$ & $\begin{array}{c}\text { Cycling activities } \\
\text { (12.3) }\end{array}$ & $\begin{array}{l}\text { Swimming activities } \\
(7.5)\end{array}$ & $\begin{array}{l}\text { Athletics, running, jogging } \\
(8.8)\end{array}$ \\
\hline 5 & $\begin{array}{l}\text { Volleyball } \\
(7.9)\end{array}$ & $\begin{array}{c}\text { Dancing activities } \\
(8.4)\end{array}$ & $\begin{array}{l}\text { Volleyball } \\
(5.6)\end{array}$ & $\begin{array}{c}\text { Dancing activities } \\
(7.3)\end{array}$ \\
\hline
\end{tabular}

sport facilities. The trend of decreasing preferences of sports gymnastics with age is obvious and results from foreign studies also confirm a decreasing interest in gymnastic activities (Hill \& Cleven, 2005). A factor that significantly influences the structure of preferences may be identified especially in the case of gymnastics. Kudláček (2010) explains the preference structure of the Czech population at the same age in his research where adolescents of various ages ranked sports gymnastics last. The factor that shapes personality during socialization since early childhood is cultural environment and habits. Differences in preferences of sports gymnastics between boys and girls require, especially during co-ed exercises, respect of interest in different gymnastic disciplines and exercises. The basic gymnastic exercises are hardly exchanged by other types of physical activities when providing for kinetic accomplishments of adolescents. Regarding gender, there was a strong correlation among preferences of individual sports that was also found by Kudláček (2010), who examined the particular topic in Czech adolescents. Regarding preferences of team sports, it was surprising that boys preferred volleyball rather than basketball. It is expected that the popularity of floorball in Poland will grow for both boys and girls. The popularity of typical European sports offers a solid ground for effective exercising and $\mathrm{PE}$, for the creation of the foundation for lifelong use of these games in simpler form and also for the use of their psychosocial benefits. The popularity of soccer in boys' preference sphere is a challenge for all types of schools and their teachers to maximally use soccer to fulfill the broadest variety of standards and competences that are required by school curricula. Using soccer only as a tool for satisfaction from PA or a tool to create a good psychosocial environment and thus fulfill boys' wishes is absolutely insufficient.
The correlation among preferences of individual sports and participation in organized PA (and moreover team sports in girls) may suggest that those who prefer these sports usually have bigger opportunities to participate in organized PA or contrary, this participation in organized PA positively influences their relationship to these sports. Therefore, this might be a tool that could help us to fight effectively against physical inactivity. Respecting the relationships among preferences and organized PA and its consecutive application in educational units should enable us to prepare conditions to enhance PA in adolescent population. For boys soccer absolutely dominates in organized PA while for girls it is volleyball. These findings correspond to findings of Bartoszewicz and Frömel (2006) as they discovered that sports games ranked first in orderliness for Polish adolescents during 2002-2003.

Attempts to promote participation in any kind of PA are more effective when they aim at needs and interests (indeed preferences) of particular target groups. Thus it is a systematic approach to the problems of PA in the context of preference sphere. In this regard, schools have a special opportunity to influence and motivate children and adolescents in the field of physical activity and healthy lifestyle.

Regular diagnostics of the preference structure of PA and preferences of sport activities of particular high school students should be undoubtedly important components to improve the current situation regarding prevalence of physical activity and healthy lifestyle. That is also expressed in other studies related to the field of preferences of physical or sport activities (Booth, Bauman, Owen, \& Gore, 1997; Burgeson, Wechsler, Brener, Young, \& Spain, 2003; Burke, Carron, \& Eys, 2006; Tammelin, Nayha, Hills, \& Jarvelin, 2003; Wilson \& Spink, 2009). 
Respecting sport preferences in the development of movement skills and fitness is seen as typical in school $\mathrm{PE}$ in the modern approach of educational process because the center of our educational attention is especially the student (Jones \& Ward, 1998; Virgilio, 2000).

\section{Strengths and weaknesses of the study}

The main contribution of the research is the practical verification of the opportunity to use the online system for research in sport preferences area - INDARES. Another strength of the study was its ability to provide the school managements and PE teachers with immediate feedback related to sport preferences of their students.

One of the limitations of the study is the section, where students express their participation in organized PA in their free time. The online version of questionnaire does not give the option to differentiate the organized PA in free time at school (extracurricular school PA lead by the teacher) from the organized PA outside school. To certain degree, another limitation might be that the completion of questionnaires took place at various times during the school year and not during vacation when students engage in different sport activities than they do during the school year. That could influence the selection of sport preferences.

\section{CONCLUSIONS}

The most preferred individual sport in 15 to 17 year old boys and girls is swimming. Regarding team sports, boys prefer soccer, volleyball, and basketball. Girls, on the other hand, prefer volleyball, basketball, and handball (including a game similar to dodgeball). Boys and girls who prefer individual sports and girls who prefer team sports participate more hours in organized PA. Diagnostics of sport preferences sphere in adolescents can contribute to the increased interest in PA and thus contribute to more effective and economic improvement of conditions for physical activity of adolescents at and outside of schools. Further research should focus on the relationships among sport preferences, sport-environmental conditions, and level of PA in adolescent boys and girls.

\section{ACKNOWLEDGEMENTS}

The study has been supported by the research grant from the Ministry of Education, Youth and Sports of the Czech Republic (No. MSM 6198959221) "Physical Activity and Inactivity of the Inhabitants of the Czech Republic in the Context of Behavioral Changes".

\section{REFERENCES}

Aaron, D. J., Storti, K. L., Robertson, R. J., Kriska, A. M., \& Laporte, R. E. (2002). Longitudinal study of the number and choice of leisure time physical activities from mid to late adolescence: implications for school curricula and community recreation programs. Archives of Pediatrics \& Adolescent Medicine, 156(11), 1075-1080.

Alexander, G. M. (2003). An evolutionary perspective of sex typed toy preferences: Pink, blue, and the brain. Archives of Sexual Behavior, 32, 7-15.

Azevedo, M. R., Araujo, C. L., Da Silva, M. C., \& Hallal, P. C. (2007). Tracking of physical activity from adolescence to adulthood: A population based study. Revista De Saude Publica, 41(1), 69-75.

Bartoszewicz, R., \& Frömel, K. (2006). Motor activity of junior high school students in the period of socioeconomic transformations in Poland and the Czech Republic. Human Movement, 7(1), 14-24.

Booth, M. L., Bauman, A., Owen, N., \& Gore, C. J. (1997). Physical activity preferences, preferred sources of assistance, and perceived barriers to increased activity among physically inactive Australians. Preventive Medicine, 26, 131-137.

Bradley, C. B., McMurray, R. G., Harrell, J. S., \& Deng, S. (2000). Changes in common activities of 3rd through 10th graders: The CHIC study. Medicine \& Science in Sports \& Exercise, 32, 2071-2078.

Burgeson, C. R., Wechsler, H., Brener, N. D., Young, J. C., \& Spain, C. G. (2003). Physical education and activity: Results from the school health policies and programs study 2000. Journal of Physical Education, Recreation \& Dance, 74(1), 20-36.

Burke, S. M., Carron, A. V., \& Eys, M. A. (2005). Physical activity context: Preferences of university students. Psychology of Sport and Exercise, 7, 1-13.

Cherney, I. D., \& London, K. (2006). Gender linked differences in the toys, television shows, computer games, and outdoor activities of 5 to 13 year old children. Sex Roles, 54, 717-726.

Cohen, J. (1988). Statistical power analysis for the behavioral sciences (2nd ed.). New York, NY: Lawrence Erlbaum Associates.

Cortina, J. M., \& Nouri, H. (2000). Effect size for ANOVA design. Thousand Oaks, CA: Sage.

Cratty, B. J. (1983). Psychology in contemporary sport: Guidelines for coaches and athletes. Englewood Cliffs, NJ: Prentice-Hall.

Eyler, A., Nanney, M. S, Brownson, R. C., Lochman, D., \& Haire-Joshu, D. (2006). Corelates of after school activity preference in children agens 5-12: The PARADE study. American Journal of Health Education, 37(2), 69-77. 
Faucette, N., Sallis, J. F., McKenzie, T., Alcaraz, J., Kolody, B., \& Nugent, P. (1995). Comparison of fourth grade students' out of school physical activity levels and choices by gender: Project spart. Journal of Health Education, 26, 82-90.

Frömel, K., Formánková, S., \& Sallis, J. F. (2002). Physical activity and sport preference of 10-14 year old children: A 5 year prospective study. Acta Universitatis Palackianae Olomucensis. Gymnica, 32(1), 11- 16 .

Frömel, K., Novosad, J., \& Svozil, Z. (1999). Pohybová aktivita a sportovní zájmy mládeže. Olomouc: Univerzita Palackého.

Greenwood, M., \& Stillwell, J. (2001). Activity preferences of middle school physical education students. The Physical Educator, 58(1), 26-30.

Hill, G., \& Cleven, B. (2005). A comparison of 9 th grade male and female physical education activities preference and support for coeducational groupings. The Physical Educator, 62(4), 187-198.

Jones, D., \& Ward, P. (1998). Changing the face of secondary physical education through sport education. Journal of Physical Education, Recreation \& Dance, 69(5), 40-45.

Kjønniksen, L., Torsheim, T., \& Wold, B. (2008). Tracking of leisure-time physical activity during adolescence and young adulthood: A 10 year longitudinal study. International Journal of Behavioral Nutrition and Physical Activity, 5, 69-79.

Kudláček, M. (2010). Sportovní preference a pohybová aktivita studentek a studentů středních škol. Disertační práce, Univerzita Palackého, Fakulta tělesné kultury, Olomouc.

McHale, S. M., Crouter, A. C., \& Whiteman, S. D. (2003). The family contexts of gender development in childhood and adolescence. Social Development, 12, 125-148.

Pate, R. R., Sallis, J. F., Ward, D. S., Stevens, J., Dowda, M., Welk, G. J., Young, D. R., Jobe, J. B., \& Strikmiller, P. K. (2010). Age related changes in types and contexts of physical activity in middle school girls. American Journal of Preventive Medicine, 39(5), 433-439.

Pate, R. R., Dowda, M., O’Neill, J. R., \& Ward, D. (2007). Change in physical activity participation among adolescent girls from 8 th to 12 th grade. Journal of Physical Activity and Health, 4, 3-16.

Pryor, J. (1994). Self-esteem and attitudes toward gender roles - contributing factors in adolescents. Australian Journal of Psychology, 46, 48-52.

Sigmund, E., Mitáš, J., Kudláček, M., \& Frömel, K. (2007). Stability of physical activity preferences survey in physical education students aged 21-24 [Abstract]. Acta Universitatis Palackianae Olomucensis. Gymnica, 37(2), 100-101.
Sigmundová, D., El Ansari, W., Sigmund, E., \& Frömel, K. (2011). Secular trends: A ten year comparison of the amount and type of physical activity and inactivity of random samples of adolescents in the Czech Republic. BMC Public Health, 11, 731. doi: 10.1186/1471-2458-11-731.

Singer, R. N., Murphey, M., \& Tennant, L. K. (1993). Handbook of research on sport psychology. New York, NY: Macmillan publishing company.

Tammelin, T., Näyhä, S., Hills, A. P., \& Järvelin, M. R. (2003). Adolescent participation in sports and adult physical activity. American Journal of Preventive Medicine, 24(1), 22-28.

Virgilio, S. J. (2000). Physical activity motivation: The missing link. Teaching Elementary Physical Education, 11(2), 5-7, 11.

Wilson, K. S., \& Spink, K. S. (2009). Social influence and physical activity in older females: Does activity preference matter? Psychology of Sport and Exercise, 10, 481-488.

\section{GENDEROVÉ ROZDÍLY PŘI VÝBĚRU INDIVIDUÁLNÍCH A KOLEKTIVNÍ SPORTŮ U POLSKÝCH ADOLESCENTŮ}

(Souhrn anglického textu)

VÝCHODISKA: Prevalence pohybové aktivity (PA) závisí z velké části na možnosti zvolit si preferovanou či oblíbenou PA. Objektivní informace o individuálních preferencích $\mathrm{v}$ rámci jednotlivých typů PA mohou úspěšně podpořit pravidelnou účast adolescentů na PA. Určení role individuálních a kolektivních sportů vzhledem ke sportovním preferencím dívek a chlapců představuje neustálý problém, který vyžaduje objektivní a průběžnou diagnostiku.

CÍL: Cílem této studie je posoudit vztah mezi preferencemi dívek a chlapců $\mathrm{v}$ rámci individuálních a kolektivních sportů, a také mezi těmito preferencemi a účastí na PA.

METODY: V Katovicích a okolí byl proveden online výzkum, jehož se zúčastnilo 518 chlapců a 559 dívek ve věku od 15 do 17 let. K účasti byly vyzvány všechny střední školy v daném regionu, zúčastnily se jej však pouze ty školy, jež umožnily výzkumné šetření. K určení preferencí mezi individuálními a kolektivními sporty byl použit dotazník preferencí v oblasti sportu, který účastnící vyplnili online v systému INDARES. Výsledky byly analyzovány za použití základních statistických metod, vztah byl určen na základě koeficientů korelace pořadí a rozdíly mezi pořadím preferovaných sportů byly ověřeny pomocí Mann-Whitneyova testu.

VÝSLEDKY: Nejpreferovanější individuální sport u dívek i chlapců je plavání a tento výsledek se týká všech věkových skupin. Mezi preferencemi dívek a chlapců 
(ve věku 15 až 17 let) v individuálních sportech existuje velmi silná korelace $(r s=.841-.895 ; p<.001)$. U dívek je nejpreferovanějším kolektivním sportem volejbal, následovaný basketbalem a házenou. Nejpreferovanější kolektivní sport u chlapců je fotbal, po němž s velkým odstupem následuje volejbal a basketbal. Vztah mezi kolektivními sporty u dívek a chlapců není tak silný jako u individuálních sportů ( $\mathrm{rs}=.745-.763$; $\mathrm{p}<.001$ ). Pokud jde o vybrané sporty, chlapci i dívky se shodli na větší oblíbenosti kolektivních sportů oproti individuálním sportům. Největší rozdíl v preferencích byl evidentní ve skupině rytmických a tanečních aktivit, jež se umístily na třetím místě u dívek, zatímco u chlapců byly na posledním místě. Dívky i chlapci preferující individuální sporty a dívky preferující kolektivní sporty se $\mathrm{v}$ hodinovém rozmezí organizované PA dané aktivity účastní déle.

ZÁVĚRY: Polská verze online systému INDARES je vhodným diagnostickým nástrojem pro zkoumání sportovních preferencí u adolescentů. Pochopení genderových rozdílů $\mathrm{v}$ rámci sportovních preferencí $\mathrm{u}$ adolescentů může zvýšit jejich účast $\mathrm{v}$ rámci organizované PA.

Klícová slova: online průzkum, typ pohybové aktivity, preference, plavání, volejbal, INDARES.

\section{Mgr. Filip Křen}

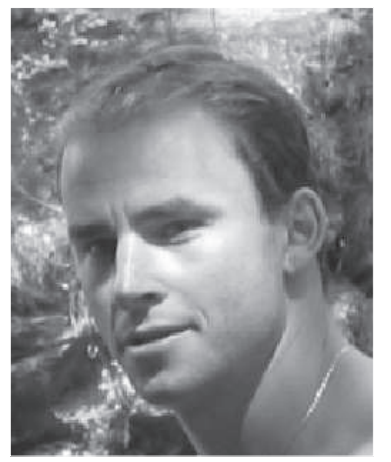

Palacký University, Olomouc Faculty of Physical Culture tř. Míru 115

77111 Olomouc

Czech Republic

\section{Education and previous work experience}

Since 2004 - postgraduate study, Palacký University, Faculty of Physical Culture.

1998-2004 - undergraduate and graduate study, Palacký University, Faculty of Physical Culture; joint majors in pedagogy of physical education $\&$ informatics.

\section{Work experience}

Since 2006 - research worker, Center for Kinanthropology Research, Palacký University.

2005 (August-December) - teaching first aid \& CPR, and physical fitness; College of Education, Valdosta State University, Valdosta, GA, USA.

\section{First-line publication}

Pelclová, J., Frömel, K., Křen, F., \& Rehor, P. (2005). Physical activity and inactivity in boys and girls of different types of schools in the Czech Republic. Journal of Coimbra Network on Excercises Science, 2(1), 8-12.

Chmelík, F., Frömel, K., Křen, F., Stelzer, J., Engelová, L., Kudláček, M. et al. (2008). The verification of the usability of the online Indares.com system in collecting data on physical activity: Pilot study. Acta Universitatis Palackianae Olomucensis. Gymnica, 38(4), 59-66. 